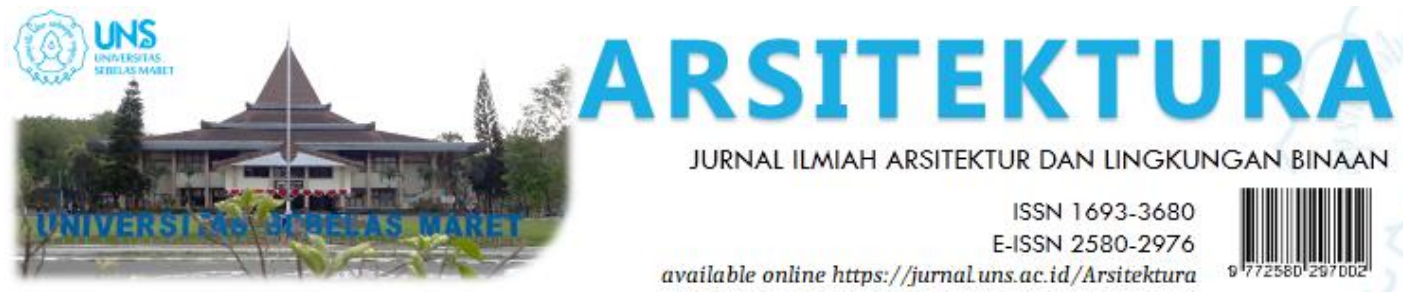

Volume 19 Issue 2 October 2021, pages:167-176

\title{
Evaluasi Desain Bangunan Berdasarkan Sistem Sertifikasi DGNB (Studi Kasus : The Khabele School, Austin)
}

\section{Design Evaluation of Building based on DGNB Certification System (Case Study : The Khabele School, Austin)}

\author{
Dady Wicaksono ${ }^{1 *}$, Sugini Sugini ${ }^{2}$ \\ Department of Architecture, Faculty of Civil Engineering and Planning, Islamic University of Indonesia ${ }^{1^{*}}$ \\ dady.wicaksana@gmail.com \\ Department of Architecture, Faculty of Civil Engineering and Planning, Islamic University of Indonesia ${ }^{2}$ \\ DOI: https://doi.org/10.20961/arst.v19i2.47150 \\ Received: December 30,2020 Revised: July 01,2021 Accepted: July 28,2021 Available online: October 30,2021
}

\begin{abstract}
The air pollution problem had become a big problem for many cities in the world. In line with the rapid development of these cities, the concept of sustainability also continues to develop with various solutions to overcome existing problems. To solve the air pollution problem, the authors evaluated the selected building object, The Khabele School, to see the extent of the building's contribution to overcoming the air pollution problem. The evaluation was carried out based on the DGNB (German Sustainable Building Council) certification system, the variables measured were biotope area factor $(B A F)$, indoor air quality, daylight factor, and zero-carbon mobility. The results reveal that indoor air quality and daylight factors could meet the desired standards, while BAF and zero-carbon mobility had not met the standard. Based on theoretical and empirical studies, this paper discussed alternative design strategies, to improve the quality of the building, so that they can contribute more to overcoming air pollution problem.
\end{abstract}

Keywords: air pollution; sustainability; rating tools; DGNB

\section{PENDAHULUAN}

Dalam beberapa tahun terakhir, sustainability atau konsep keberlanjutan telah bergaung dimana-mana. Konsep tersebut terus digaungkan sejalan dengan berkembang pesatnya pembangunan kota-kota di seluruh dunia. Berdasarkan data yang dikeluarkan oleh United Nations, urbanisasi berlangsung begitu cepat dan pertumbuhan populasi global mengalami lonjakan jumlah penduduk perkotaan dari 751 juta pada tahun 1950 menjadi 4,2 miliar pada tahun 2018. Populasi penduduk meningkat, begitu juga dengan jumlah kota besar. Seiring perkembangan skala kota, masalah-masalah mengenai polusi udara pun menjadi sangat banyak, seperti masalah polutan yang berhubungan dengan lalu lintas telah mencapai proporsi yang tinggi dan telah menjadi sumber utama polusi udara di beberapa kota besar termasuk Beijing, Tianjin dan Shanghai (Lu, Li, Li, \& Al-Barakani, 2021), masalah perubahan iklim tidak hanya mempengaruhi kenyamanan hunian manusia tetapi cuaca ekstrim yang terjadi juga membahayakan kesehatan, perubahan suhu lingkungan dapat menyebabkan stres fisiologis dan mengubah respons fisiologis seseorang terhadap polutan yang beracun dan berbahaya 
(Zhang et al., 2020), masalah kesehatan yang terjadi karena udara tercemar oleh gas dan partikel, terjadi pada bagian fungsi organ penting di tubuh contohnya paru-paru dan pembuluh darah, serta menimbulkan iritasi pada mata dan kulit (Kusminingrum, 2018). Oleh karena itu, kualitas udara perkotaan harus segera dikelola, dan faktor-faktor yang dapat memperburuk sumber pencemaran udara harus dikontrol secara ketat untuk menurunkan tingkat polusi udara.

Dalam mengatasi permasalahan polusi udara di tingkat urban maupun setingkat pada badan jalan, muncul solusi dari hasil penelitian di berbagai penjuru dunia dengan berbagai kondisi dan masalah, contohnya yang pertama dengan mempertimbangkan bentuk morfologi bangunan dan bentuk spasial karena dapat mempengaruhi kondisi angin dengan menghalangi, mengurangi, atau memperkuat aliran udara baik pada tingkat makroskopis maupun mikroskopis (Yang et al., 2020). Kedua, untuk lokasi yang hanya mempunyai lahan sempit misalnya di perkotaan terutama di sepanjang badan jalan yang sempit, metode vertical garden dapat dimanfaatkan untuk memaksimalkan penyerapan udara, sehingga tingkat efektifitasnya dapat meningkat dalam mengurangi polusi udara. Tanaman semak disarankan dalam solusi ini karena dapat mereduksi NOx dengan baik, dapat bertahan dibawah terik matahari, pertumbuhannya tidak terlalu cepat dan bukan jenis tanaman rambat (Kusminingrum, 2018).

Ketiga, selain solusi fisik ada juga solusi tertulis, misalnya yaitu dengan menemukan indeks baru dari meteorology and environment comfort (MEC) yang tidak hanya mempertimbangkan kondisi meteorologi namun juga mempertimbangkan polusi udara (Zhang et al., 2020), solusi ini menjawab bahwa belum tentu cuaca dingin itu nyaman, bisa juga terjadi cuaca dingin namun kandungan polusi udaranya tinggi, sehingga tidak nyaman. Keempat, dengan melihat faktor lain seperti sosial, ekonomi, kondisi lalu lintas, pemerintah harus dapat mengefektifkan program perencanaan kota dan kebijakan transportasi, sehingga dapat meningkatkan kualitas lingkungan perkotaan (Lu et al., 2021).
Pembangunan berkelanjutan adalah pendekatan holistik yang harus mencakup seluruh bagian. Untuk memastikan kualitas dari sudut pandang sosial, lingkungan dan ekonomi suatu bangunan, sekarang ini berbagai stakeholders membuat sistem sertifikasi yang dapat membuktikan dan meningkatkan serta membantu pihak-pihak terkait untuk mengembangkan keberlanjutan. Ada berbagai macam sertifikasi atau rating tools, salah satunya adalah sistem sertifikasi dari Jerman yaitu DGNB (German Sustainable Building Council).

DGNB adalah sistem sertifikasi yang dikembangkan di Jerman dan didirikan pada tahun 2007. Sistem DGNB digunakan pada semua tahap bangunan, dari mulai konstruksi hingga pada tahap akhir bangunan, atau penghancuran bangunan. Hal ini memberikan transparasi yang lebih besar, gambaran proses yang lebih baik, serta meminimalkan resiko selama konstruksi, pengoperasian, renovasi dan peralihan fungsi maupun penghancuran. DGNB tidak hanya berfokus pada tiga pilar utama (lingkungan, ekonomi, dan sosial budaya) namun juga fungsional, proses, dan lokasi bangunan.

Bangunan yang menjadi objek evaluasi adalah The Khabele School. Bangunan tersebut dipilih karena memiliki konsep yang menarik yaitu "village in the forest". Konsep ini perlu ditinjau lebih dalam apakah dengan konsep tersebut bangunan telah mampu memberikan andil dalam mengatasi permasalahan yang ada sekarang ini, terutama polusi udara. The Khabele School berada di Austin, Texas, lokasinya berada dekat dengan ruang hijau taman kota. Fungsi dari bangunannya sendiri sebagai sekolah yang diperuntukan bagi anak usia dini atau preschool hingga tingkat sekolah dasar, dan dilengkapi pula dengan fasilitas daycare.

Tujuan dari penelitian ini adalah untuk mengevaluasi konsep "village in the forest" dalam menerapkan aspek green building terutama dalam menangani isu polusi udara berdasarkan sistem sertifikasi DGNB. Sehingga diharapkan hasil evaluasi dan solusi yang dihasilkan, dapat menjadi referensi dalam mengatasi isu polusi udara dengan desain bangunan yang berwawasan lingkungan. 


\section{METODE}

DGNB memiliki 4 jenis kategori dalam sistem sertifikasi bergantung pada fungsi dan jenis bangunan yang akan dievaluasi. Dalam evaluasi ini, penulis menggunakan kategori "DGNBBuilding in Use, karena objek bangunan yang dievaluasi merupakan bangunan yang telah digunakan sebagai sekolah sesuai dengan fungsi utamanya.

Isu polusi udara yang telah meningkat, menjadi masalah di setiap negara, berbagai solusi yang diupayakan oleh peniliti, teknologi dan berbagai bidang ilmu lainnya selalu dikembangkan untuk menekan polusi udara. Berdasarkan isu polusi udara serta hasil pengumpulan data dan informasi dasar yang didapat dari objek bangunan, maka penulis telah menentukan variabel, parameter dan indikator, serta metode evaluasi yang akan digunakan dalam evaluasi bangunan, sebagai berikut.

\subsection{Biotope Area Factor (BAF)}

BAF adalah suatu strategi yang terbentuk di Jerman, untuk dapat menjaga ruang hijau di dalam kawasan terbangun. Metode yang dilakukan dengan menentukan kelompok kelompok penutup tanah yang ada di kawasan terbangun, setiap penutup tanah yang berbeda memiliki nilai faktor yang berbeda, seperti pada tabel 1 di bawah ini.

Tabel 1. Nilai faktor setiap penutup tanah

\begin{tabular}{lc}
\hline \multicolumn{2}{l}{ Biodiversity indices for sub-area } \\
\hline Sealed surfaces & 0 \\
\hline Partially sealed surfaces & 0.3 \\
\hline Semi-open surfaces & 0.5 \\
\hline $\begin{array}{l}\text { Surfaces with vegetation, } \\
\text { unconnected to the soil } \\
\text { below < 80cm }\end{array}$ & 0.5 \\
\hline $\begin{array}{l}\text { urfaces with vegetation, } \\
\text { unconnected to the soil } \\
\text { below > 80cm }\end{array}$ & 0.7 \\
\hline $\begin{array}{l}\text { Surfaces with vegetation, } \\
\text { connected to the soil } \\
\text { below }\end{array}$ & 1 \\
\hline $\begin{array}{l}\text { Rainwater infiltration per } \\
\text { m } \text { of roof area }\end{array}$ & 0.2 \\
\hline $\begin{array}{l}\text { Vertical greenery up to } \\
\text { max } 10 \text { m in height }\end{array}$ & $0.5-0.7$ \\
\hline Greenery on rooftop & $0.5-0.8$ \\
\hline
\end{tabular}

Setelah menentukan nilai faktor di atas, kemudian mencari nilai BAF dengan persamaan sebagai berikut.

$$
\mathrm{BAF}=\frac{\text { effective surface area }}{\text { total land area }}
$$

\subsection{Indoor Air Quality (IAQ)}

IAQ adalah nilai kualitas udara di suatu ruangan karena pada dasarnya polusi udara tidak hanya terjadi di luar ruangan, namun dapat terjadi di dalam ruangan. IAQ yang buruk dapat menyebabkan gangguan kesehatan bagi pengguna bangunan, terlebih bila digunakan jangka waktu yang lama. Pada kasus bangunan Khabele School yang mana difungsikan untuk anak-anak yang masih di bawah umur, bangunan harus dapat menjaga penggunanya tidak hanya dari cuaca namun juga dari kualitas udara di dalam ruang. Metode yang digunakan dalam mengevaluasi IAQ dalam DGNB bersumber pada ASHREA standard 62.1-2013 yaitu dengan menggunakan persamaan berikut.

$$
V b z=R p \times P z+R a \times A z
$$

$$
\begin{array}{ll}
V b z & : \text { total ventilation rate }(l / s) \\
R p & : \text { outdoor airflow rate per person }(l / s . p e r s o n) \\
P z & : \text { zone population } \\
R a & : \text { outdoor airflow rate per unit area }(l / s . m 2) \\
A z & : \text { zone floor area }(\mathrm{m} 2)
\end{array}
$$

\subsection{Daylight Factor (DF)}

Daylight Factor (DF) adalah metrik yang menunjukan jumlah cahaya alami yang tersedia di dalam ruangan (di bidang kerja) dibandingkan dengan jumlah cahaya alami yang tersedia di luar tanpa terhalang objek apapun dalam kondisi langit mendung. Semakin tinggi DF, semakin banyak cahaya matahari tersedia di dalam ruangan. DGNB merujuk pada standar EN-17037 tentang Daylight Standard. Metode yang digunakan yaitu dengan uji simulasi menggunakan software Velux Daylight Visualizer versi 3.0

\subsection{Zero Carbon Mobility}

Zero carbon mobility merupakan sebuah konsep untuk mengurangi emisi karbon yang disebabkan oleh penggunaan kendaraan bermotor. Hal tersebut sangat berkaitan dengan isu yang diambil mengenai polusi udara, di mana telah menjadi rahasia umum bahwa kendaraan merupakan salah satu penyumbang gas emisi karbon terbesar. 
Merujuk pada sistem DGNB, dalam mengevaluasi indikator ini penulis melakukan analisis kawasan terbangun, penilaian didapat dari ketersediaan infrastruktur bangunan dalam mendukung penekanan emisi gas buang, yang disajikan dalam bentuk checklist ketersediaan infrastruktur bangunan.

\section{HASIL DAN PEMBAHASAN}

\subsection{Hasil Evaluasi Bangunan}

\section{Biotope Area Factor (BAF)}

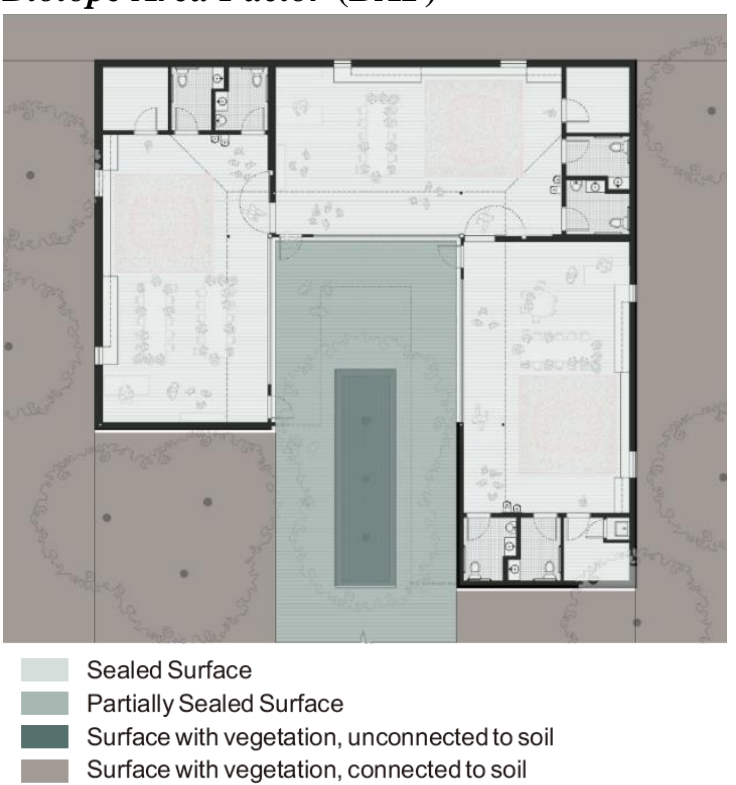

Gambar 1. Penutup Tanah

Sumber: Data analisis kawasan terbangun, 2020

Dari data di atas, didapatkan beberapa jenis penutup tanah pada kawasan terbangun. Setiap jenis penutup atap memiliki faktor pengali yang berbeda-beda, nilai faktor yang tertinggi adalah 1,0 sedangkan yang terendah yaitu 0,0 . Semakin tinggi nilai faktor maka semakin baik penutup tanah tersebut dalam tingkat penyerapannya. Nilai faktor tersebut akan dikalikan dengan luasannya yang kemudian dibandingkan dengan luas kawasan terbangun keseluruhan, sehingga dapat menghasilkan nilai BAF.
Tabel 2. Hasil evaluasi Biotope Area Factor (BAF) pada bangunan The Khabele School

\begin{tabular}{|c|c|c|}
\hline Surface type & Area & EEA \\
\hline $\begin{array}{ll}\text { Sealed surfaces } & \mathbf{0 . 0} \\
\end{array}$ & 318 & 0 \\
\hline Partially sealed surfaces $\mathbf{0 . 3}$ & 152.52 & 45.756 \\
\hline Semi-open surfaces $\mathbf{0 . 5}$ & & \\
\hline $\begin{array}{l}\text { Surfaces with vegetation, } \\
\text { unconnected to the soil below } \\
<80 \mathrm{~cm} \mathbf{0 . 5}\end{array}$ & & \\
\hline $\begin{array}{l}\text { urfaces with vegetation, } \\
\text { unconnected to the soil below } \\
>80 \mathrm{~cm} \mathbf{0 . 7}\end{array}$ & 21.48 & 15.036 \\
\hline $\begin{array}{l}\text { Surfaces with vegetation, } \\
\text { connected to the soil below } \mathbf{1}\end{array}$ & 307.47 & 307.47 \\
\hline $\begin{array}{l}\text { Rainwater infiltration per } \mathrm{m}^{2} \\
\text { of roof area } \mathbf{0 . 2}\end{array}$ & & \\
\hline $\begin{array}{l}\text { Vertical greenery up to max } \\
10 \mathrm{~m} \text { in height } \mathbf{0 . 5}-\mathbf{0 . 7}\end{array}$ & & \\
\hline Greenery on rooftop $\mathbf{0 . 5}-\mathbf{0 . 8}$ & & \\
\hline Efective surface Area Total & & 368.26 \\
\hline $\mathrm{BAF}=\frac{368.262}{799.47}$ & \multicolumn{2}{|c|}{$\mathrm{BAF}=0.4606$} \\
\hline
\end{tabular}

\section{Indoor Air Quality (IAQ)}

Pergantian udara dapat memengaruhi AC dan pemanas serta energi kipas dalam sistem AC. Evaluasi IAQ menggunakan perhitungan sesuai dengan ASHRAE Standard 62.1 yang menjelaskan cara menghitung kebutuhan aliran udara, yang memiliki pengaruh signifikan pada desain dan kontrol sistem ventilasi.

Tabel 3. Data luas ruang kelas

\begin{tabular}{lccc}
\hline Nama Ruang & \multicolumn{3}{c}{ Luas } \\
\cline { 2 - 4 } & $\begin{array}{c}\text { Panjang } \\
(\mathrm{m})\end{array}$ & $\begin{array}{c}\text { Lebar } \\
(\mathrm{m})\end{array}$ & $\begin{array}{c}\text { Total } \\
\left(\mathrm{m}^{2}\right)\end{array}$ \\
Classroom 1 & 25.98 & 38.04 & 45.67 \\
Classroom 2 & 29.63 & 49.59 & 56.95 \\
Classroom 3 & 28.87 & 48.94 & 53.02 \\
\hline
\end{tabular}

Dari data luas ruang yang ada, kemudian didapatkan hasil evaluasi (Tabel 4) dengan memperhatikan kepadatan ruang dan laju aliran udara yang terjadi.

Tabel 4. Hasil evaluasi Indoor Air Quality (IAQ)

\begin{tabular}{|c|c|c|c|c|c|c|c|c|c|}
\hline \multirow{2}{*}{$\begin{array}{l}\text { Nama } \\
\text { Ruang }\end{array}$} & \multicolumn{2}{|c|}{$\mathrm{Rp}$} & \multicolumn{2}{|c|}{$\mathrm{Pz}$} & \multicolumn{2}{|c|}{$\mathrm{Ra}$} & \multirow{2}{*}{$\begin{array}{c}\mathrm{Az} \\
\mathrm{m}^{2}\end{array}$} & \multicolumn{2}{|c|}{$\mathrm{Vbz}$} \\
\hline & $\mathrm{cfm} /$ person & L/s.person & $\mathrm{m}^{2} /$ person & person & $\mathrm{cfm} / \mathrm{ft}^{2}$ & $\mathrm{~L} / \mathrm{s} \cdot \mathrm{m}^{2}$ & & $\mathrm{~L} / \mathrm{s}$ & L/s.person \\
\hline Classroom 1 & 10 & 5 & 4 & 20.99 & 0.12 & 0.6 & 83.96 & 155.32 & 7.4 \\
\hline Classroom 2 & 10 & 5 & 4 & 19.99 & 0.12 & 0.6 & 79.97 & 147.93 & 7.4 \\
\hline Classroom 3 & 10 & 5 & 4 & 21.85 & 0.12 & 0.6 & 87.40 & 161.69 & 7.4 \\
\hline
\end{tabular}




\section{Daylight Factor (DF)}

Dalam evaluasi DF, tidak keseluruhan ruang dilakukan uji simulasi, hanya ruang utama atau ruang yang menjadi kegiatan belajar mengajar dilakukan yaitu ruang kelas. Terdapat 3 ruang kelas yang dilakukan evaluasi, dapat dilihat pada Gambar 2.

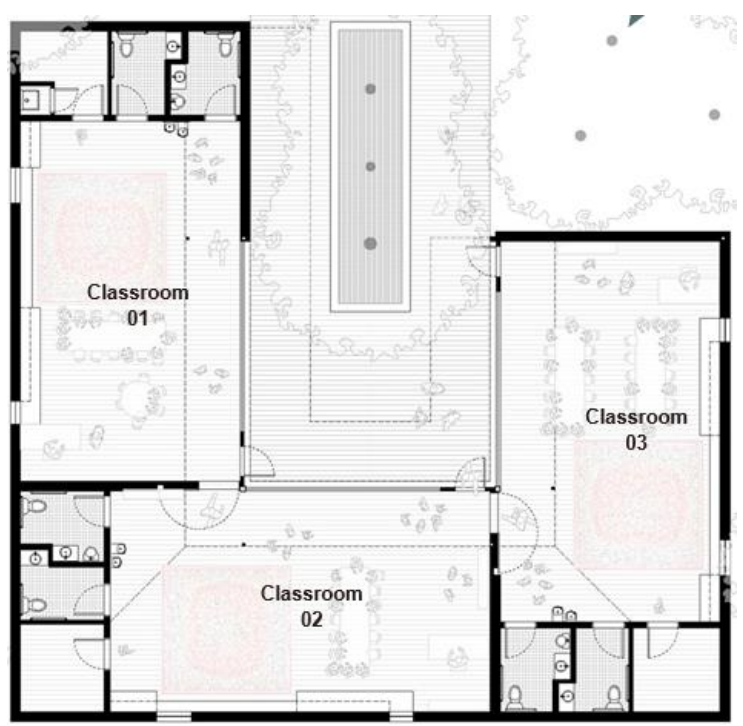

Gambar 2. Denah The Khabele School

Sumber: archdaily.com/777586, 2015

Uji simulasi dilakukan dengan software Velux daylight visualizer, sesuai dengan kondisi existing yang ada. Sehingga memimalkan perbedaan hasil simulasi dengan keadaan di lapangan.

Tabel 5. Hasil simulasi Velux Daylight Visualizer

\begin{tabular}{|c|c|c|c|}
\hline Nama Ruang & Velux DF & & \\
\hline \multirow{7}{*}{ Ruang Kelas 01} & & DF Average & 2,86 \\
\hline & & DF Median & 2,67 \\
\hline & & DF Minimum & 0,59 \\
\hline & & DF Maximum & 8,67 \\
\hline & & Uniformity 1 & 0,21 \\
\hline & & Uniformity 2 & 0,07 \\
\hline & & Above $0,7 \%$ & $99,41 \%$ \\
\hline \multirow{7}{*}{ Ruang Kelas 02} & & DF Average & 2,65 \\
\hline & & DF Median & 2,64 \\
\hline & & DF Minimum & 0,44 \\
\hline & & DF Maximum & 8 \\
\hline & & Uniformity 1 & 0,21 \\
\hline & & Uniformity 2 & 0,07 \\
\hline & & Above $0,7 \%$ & $99,41 \%$ \\
\hline \multirow{7}{*}{ Ruang Kelas 03} & \multirow{7}{*}{ C } & DF Average & 2,55 \\
\hline & & DF Median & 2,28 \\
\hline & & DF Minimum & 0,47 \\
\hline & & DF Maximum & 8,35 \\
\hline & & Uniformity 1 & 0,21 \\
\hline & & Uniformity 2 & 0,07 \\
\hline & & Above $0,7 \%$ & 99,41 \\
\hline
\end{tabular}

\section{Zero Carbon Mobility}

Evaluasi zero carbon mobility lebih mengutamakan ketersediaan infrastruktur pendukung program-program penekanan emisi gas karbon, seperti infrastruktur untuk pesepeda, transportasi umum, dan mode transportasi terbarukan. Hasil evaluasi berupa daftar checklists (lihat Tabel 6).

Tabel 6. Hasil evaluasi daftar checklist infrastruktur pendukung zero carbon mobility

\begin{tabular}{|c|c|c|c|c|}
\hline Indikator & Tolak ukur & Ada & $\begin{array}{c}\text { Tidak } \\
\text { Ada } \\
\end{array}$ & Poin \\
\hline Pedestrian & $\begin{array}{l}\text { Infrastruktur jalur } \\
\text { pejalan kaki }\end{array}$ & $\mathrm{v}$ & & 5 \\
\hline \multirow{6}{*}{ Sepeda } & $\begin{array}{l}\text { Parkir mudah } \\
\text { diakses }\end{array}$ & & $\mathrm{v}$ & 5 \\
\hline & $\begin{array}{l}\text { Parkir terlindung } \\
\text { dari cuaca min } 80 \%\end{array}$ & & $\mathrm{v}$ & 5 \\
\hline & $\begin{array}{l}\text { Pencahayaan parkir } \\
\text { memadai min } 80 \%\end{array}$ & & $\mathrm{v}$ & 5 \\
\hline & Parkir aman & & $\mathrm{v}$ & 5 \\
\hline & Bengkel sepeda & & $\mathrm{v}$ & 5 \\
\hline & Pom listrik & & $\mathrm{v}$ & 10 \\
\hline \multirow{2}{*}{$\begin{array}{l}\text { Kendaraan } \\
\text { umum }\end{array}$} & $\begin{array}{l}\text { Jarak pemberhentian } \\
\text { max } 350 \mathrm{~m}\end{array}$ & & $\mathrm{v}$ & 10 \\
\hline & $\begin{array}{l}\text { Infrastruktur } \\
\text { pendukung }\end{array}$ & & $\mathrm{v}$ & 15 \\
\hline $\begin{array}{l}\text { Kendaraan } \\
\text { pribadi }\end{array}$ & $\begin{array}{l}\text { Pom listrik } \\
\text { kendaraan }\end{array}$ & & $\mathrm{v}$ & 5 \\
\hline $\begin{array}{l}\text { Kendaraan } \\
\text { bersama }\end{array}$ & $\begin{array}{l}\text { Kendaraan bersama } \\
\text { tersedia }\end{array}$ & $\mathrm{v}$ & & 10 \\
\hline
\end{tabular}

\subsection{Rekomendasi Desain dan Teknologi}

\section{Biotope Area Factor (BAF)}

Berdasarkan hasil evaluasi yang dilakukan dalam aspek Biotope Area Factor (BAF), The Khabele School tidak dapat memenuhi standar yang ditetapkan dalam BAF tersebut. Standar yang diminta berdasarkan The Berlin Senate Department for the Environment Transport and Climate Protection untuk lingkungan Nursery School and Day Care Centres adalah 0,6 sedangkan hasil yang didapat hanya 0,46 .

Oleh karena itu perlu strategi desain yang dapat memaksimalkan pada aspek BAF tersebut. Mempertimbangkan keterbatasan lahan yang ada, maka rekomendasi yang diberikan adalah dengan memaksimalkan green walls karena masih banyak ruang dinding kosong yang dapat dimanfaatkan untuk meningkatkan nilai sustainable bangunan dan nilai BAF tentunya. 

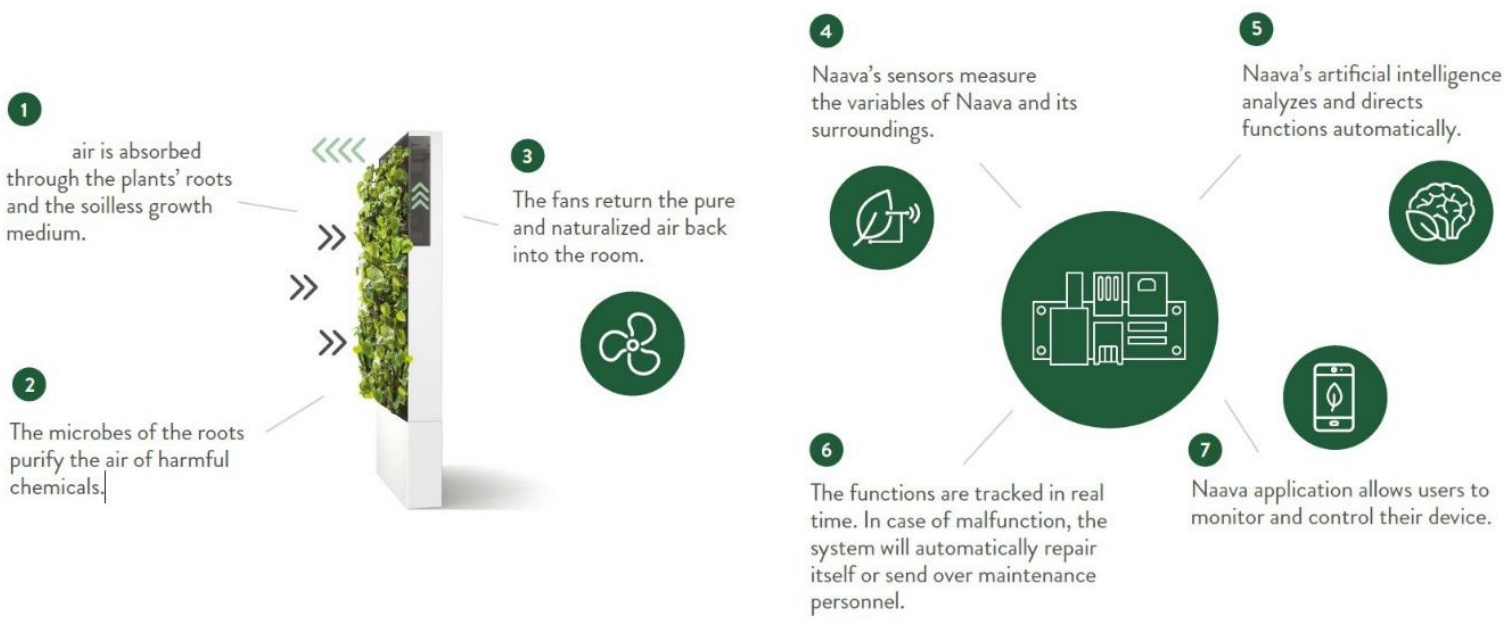

Gambar 3. Sistem teknologi Naava Smart Green Walls Sumber: naava.io/en/, 2017

Sistem teknologi green walls yang dipilih untuk menjadi solusi di bangunan The Khabele School adalah Naava Smart Green Walls (lihat Gambar 3). Pemilihan teknologi tersebut karena flexible solution, mudah untuk dipindahkan dan dapat disesuaikan dengan fungsi ruang, dapat digunakan indoor maupun outdoor. One product many functions, dapat berfungsi sebagai pembersih udara, dilengkapi dengan sensor yang mendukung kinerja, mengatur kelembapan dan juga dapat menjadi elemen akustik bangunan. Easy maintenance, mengingat fungsi bangunan digunakan oleh kelompok usia anak-anak, sehingga perawatan yang mudah menjadi faktor yang perlu diperhatikan dalam penggunaan green walls.

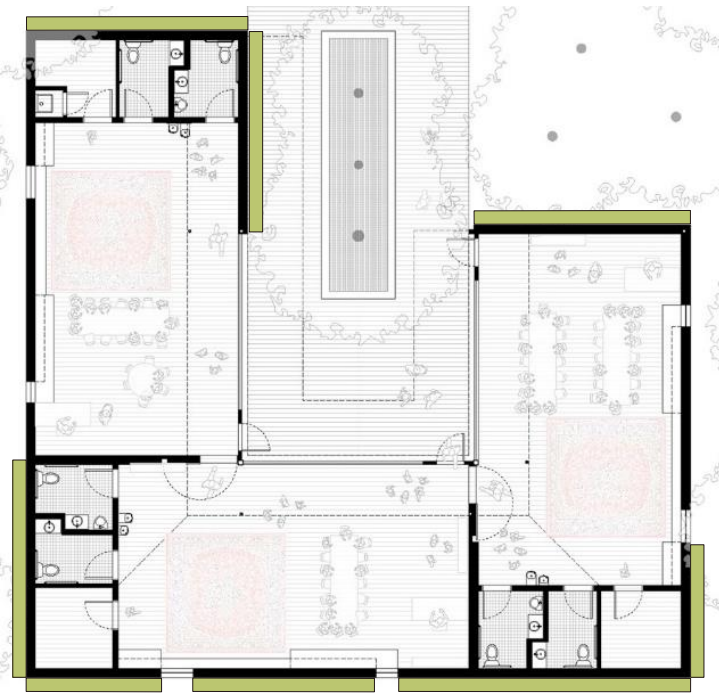

Gambar 4. Denah perletakan green walls Sumber: Hasil analisis rekomendasi desain, 2020
Untuk melihat rekomendasi desain tersebut sudah dapat memenuhi standar yang ada, maka dilakukan evaluasi ulang, dengan metode penilaian yang sama. Pada Tabel 7, memperlihatkan hasil nilai BAF setelah penerapan rekomendasi desain mengalami peningkatan dari 0,46 menjadi 0,61 . Sehingga telah mampu memenuhi standar yang digunakan.

Tabel 7. Hasil evaluasi ulang BAF dengan menerapkan rekomendasi desain

\begin{tabular}{lcc}
\hline Surface type & Area & EEA \\
\hline Sealed surfaces $\mathbf{0 . 0}$ & 318 & 0 \\
\hline Partially sealed surfaces $\mathbf{0 . 3}$ & 152.52 & 45.756 \\
\hline Semi-open surfaces $\mathbf{0 . 5}$ & & \\
\hline $\begin{array}{l}\text { Surfaces with vegetation, } \\
\text { unconnected to the soil below } \\
<80 \mathrm{~cm} \mathbf{0 . 5}\end{array}$ & & \\
\hline $\begin{array}{l}\text { urfaces with vegetation, } \\
\text { unconnected to the soil below } \\
>\text { 80cm } \mathbf{0 . 7}\end{array}$ & 21.48 & 15.036 \\
\hline $\begin{array}{l}\text { Surfaces with vegetation, } \\
\text { connected to the soil below } \mathbf{1}\end{array}$ & 307.47 & 307.47 \\
\hline $\begin{array}{l}\text { Rainwater infiltration per m }{ }^{2} \\
\text { of roof area } \mathbf{0 . 2}\end{array}$ & & \\
\hline $\begin{array}{l}\text { Vertical greenery up to max } \\
10 \text { m in height } \mathbf{0 . 5}-\mathbf{0 . 7}\end{array}$ & 115 & 80.5 \\
\hline Greenery on rooftop $\mathbf{0 . 5}-\mathbf{0 . 8}$ & 42.9 & 33.832 \\
\hline Efective surface Area Total & & $\mathbf{4 8 2 . 5 9}$ \\
\hline \multicolumn{1}{c}{ BAF $=\frac{482.59}{799.47}$} & BAF $=\mathbf{0 . 6 1}$ \\
\hline
\end{tabular}

\section{Indoor Air Quality \& Daylight Factor}

Nilai indoor air quality (IAQ) yang buruk menyebabkan berbagai gejala alergi seperti melemahnya sistem imun dan gangguan 
pernafasan, dan lain sebagainya. Secara spesifik, anak-anak rentan terhadap begitu banyak masalah kesehatan dari udara dalam ruangan yang terkontaminasi karena paru-paru mereka sangat kecil.

Berdasarkan ASHREA 62.1 nilai IAQ yang optimal untuk ruang kelas adalah $8 \mathrm{~L} / \mathrm{s}$ per person, untuk batas yang dapat diterima adalah disekitar $\pm 7,5 \mathrm{~L} / \mathrm{s}$ per person. Dari hasil evaluasi, setiap ruang kelas dapat mencapai 7,4 $\mathrm{L} / \mathrm{s}$ per person sehingga sudah dapat mencukupi sirkulasi udara dalam ruangan. Untuk memberikan hasil yang maksimal penulis memberikan rekomendasi desain pertama dengan meningkatkan ventilasi udara, dengan meningkatkan ventilasi udara diharapkan terjadi sirkulasi udara yang lebih baik, sehingga kondisi ruangan tetap terjaga.

Dalam aspek daylight factor (DF) sudah dapat melewati batas standar, pada standar EN-17037 tentang Daylight Standard, dimana daylight faktor minimum $0,7 \%$ harus dipenuhi pada $95 \%$ permukaan tanah. Dapat dilihat pada Tabel 5, semua ruang kelas dengan daylight faktor minimum $0,7 \%$ dapat terpenuhi hingga $99,41 \%$. Namun perlu menjadi catatan di dalam hasil simulasi Velux Daylight Visualizer pada beberapa bagian sudut ruangan memiliki nilai DF yang cukup kecil. Hal ini menunjukan pencahayaan alami yang jatuh ke ruang kelas belum merata. Belum meratanya pencahayaan ini diakibatkan adanya dinding masif di bagian sudut setiap kelas.

Aspek IAQ dan DF pada The Khabele School sudah dapat mencapai target yang menjadi standar yang ada dalam DGNB. Namun walaupun sudah mencapai target yang diharapkan, masih ada kekurangan yang dapat ditingkatkan, sehingga bangunan dapat menjadi lebih baik lagi. Mempertimbangkan aspek daylight dan indoor air quality memiliki kedekatan yang berhubungan yaitu bukaan, sehingga menggabungkan aspek keduanya dengan rekomendasi desain yang bersamaan menjadi solusi yang lebih baik dengan menambahkan bukaan skylight. Sistem teknologi yang digunakan yaitu Velux Skylight bertenaga surya, pemilihan teknologi tersebut didasarkan pada fungsinya sebagai ventilation, penggunaan skylight yang dapat dibuka dan ditutup akan memperlancar pergantian udara di dalam dan luar bangunan. Rain detection, skylight sudah dilengkapi dengan sensor hujan, ketika skylight terkena air maka akan otomatis tertutup. Lower Electric Bill, dengan penggunaan skylight maka akan menurunkan penggunaan lampu. Indoor climate sensors, skylight juga dilengkapi dengan sensor $\mathrm{CO}$, kelembapan dan temperatur.

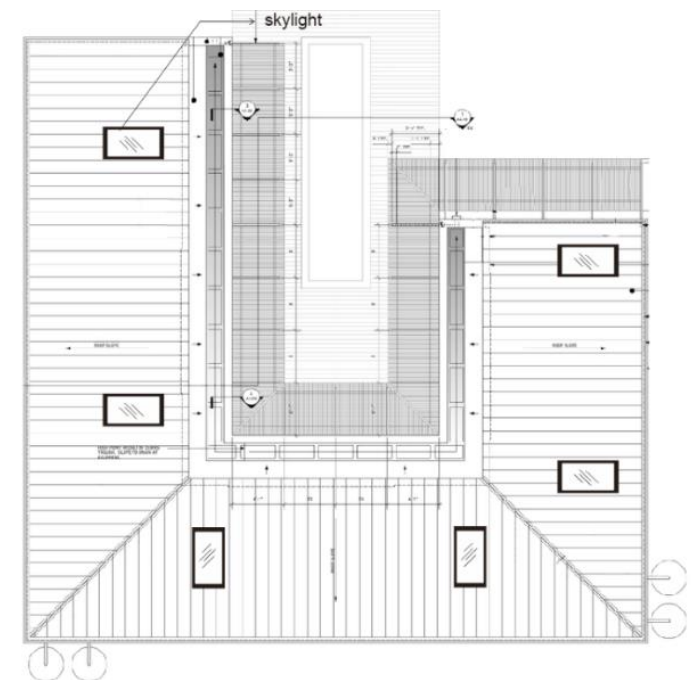

Gambar 5. Denah atap perletakan skylight Sumber: Hasil analisis rekomendasi desain, 2020

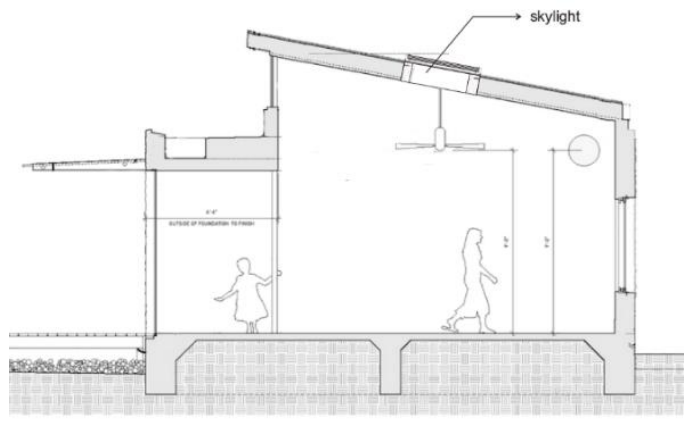

Gambar 6. Potongan perletakan skylight

Sumber: Hasil analisis rekomendasi desain, 2020

Hasil evaluasi ulang (Gambar 7) dengan menggunakan rekomendasi desain dapat dilihat perbedaan pada area sudut bangunan. Pada desain awal sudut bangunan memiliki nilai DF yang cukup rendah, sedangkan pada desain rekomendasi memperlihatkan pencahayaan jatuh lebih merata. Untuk IAQ, dengan sensor yang dimiliki skylight seperti tempertatur, kelembapan dan $\mathrm{CO} 2$, dapat menjaga kondisi udara yang baik di dalam ruang.

\section{Zero Carbon Mobility}




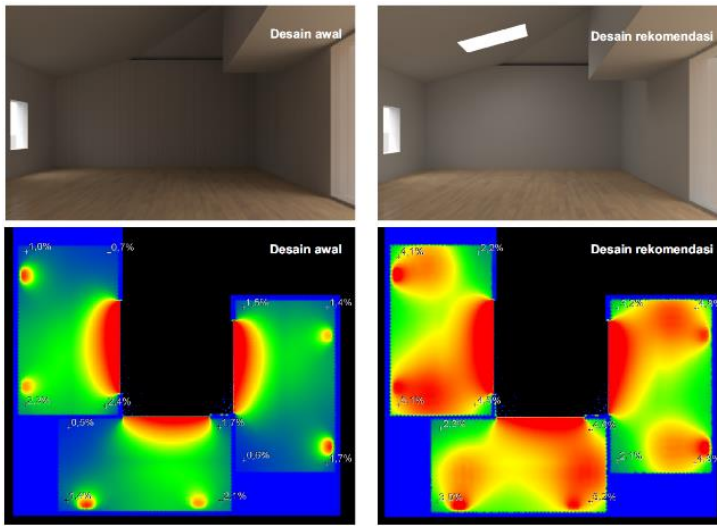

Gambar 7. Perbandingan desain awal dan desain rekomendasi

Sumber: Hasil evaluasi Velux, 2020

Pada hasil evaluasi zero carbon mobility, yang mana penilaiannya menggunakan tabel checklist, The Khabele School masih meninggalkan banyak poin yang seharusnya bisa didapat. Dari total 80 poin yang bisa didapatkan dalam sistem setifikasi DGNB, The Khabele School hanya mendapatkan 15 poin saja. Hal ini menunjukan desain bangunan belum secara penuh mendukung program penekanan emisi karbon pada kendaraan. Strategi yang dapat dilakukan yaitu dengan menambahkan sejumlah infrastruktur yang disesuaikan dengan fungsi bangunan, sehingga dapat meningkatkan poin yang didapat, serta bangunan dapat turut andil dalam mendukung penekanan emosi karbon pada kendaraan.

Infrastruktur yang mungkin untuk dikembangkan di bangunan dan lingkungan The Khabele School, adalah menambahkan infrastruktur di aspek sepeda, karena kemungkinan siswa dapat menggunakan sepeda untuk menuju ke sekolah. Aspek kendaraan umum, melihat data yang tersedia, terdapat jalur metrobus Austin, yang melalui area tersebut, dapat menambahkan infrastruktur pemberhentian bus.

Untuk memberikan nilai lebih ke bangunan, maka diperlukan suatu teknologi yang dapat bermanfaat bagi bangunan dan juga bagi lingkungan, sehingga tidak hanya mendapatkan nilai lebih pada DGNB namun juga memberikan nilai sustainable yang lebih baik. Teknologi yang digunakan yaitu PaveGen Kinetic Tiles, merupakan sebuah inovasi yang dikembangkan dari paving slab yang dapat mengubah energi kinetik dari langkah pejalan kaki menjadi tenaga listrik. Tenaga listrik tersebut dapat disimpan untuk disalurkan ke fixture-fixture di bangunan sehingga menjadi energi alternatif. PaveGen Kinetic Tiles, terdiri dari 3 komponen utama yang harus ada agar dapat bekerja dengan baik, yaitu electromagnetic generator, single triangular composite tile dan tekanan orang ketika berjalan. Satu langkah kaki dapat menghasilkan energi listrik sebesar 4 sampai 7 watt, yang bisa menyalakan sebuah lampu LED selama 1 detik.

Rekomendasi desain tersebut kemudian dikombinasikan dengan teknologi pavegen. Dengan mengubah satu ruas jalan kendaraan bermotor dialih fungsikan menjadi jalur pesepeda dan juga pejalan kaki. Pada jalur tersebut ditanamkan teknologi pavegen, sehingga ketika orang melewatinya teknologi ini dapat mengubah energi kinetik menjadi energi listrik, yang dapat digunakan untuk lampu jalan dan lampu parker serta juga dapat disalurkan ke fixture-fixture di dalam bangunan.

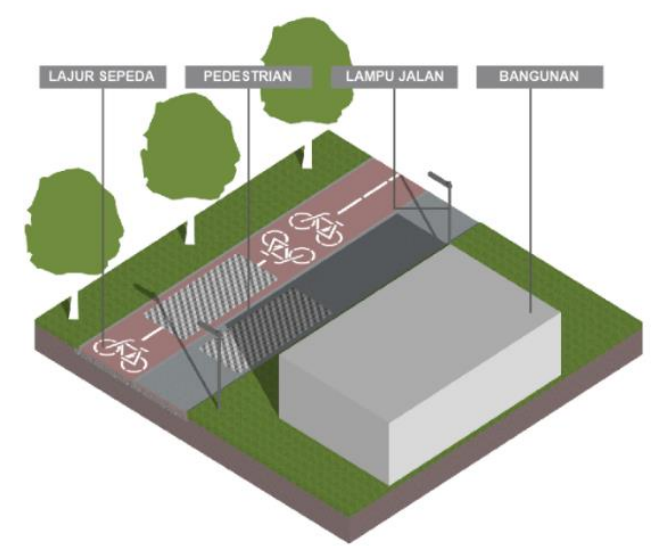

Gambar 8. Ilustrasi rekomendasi desain

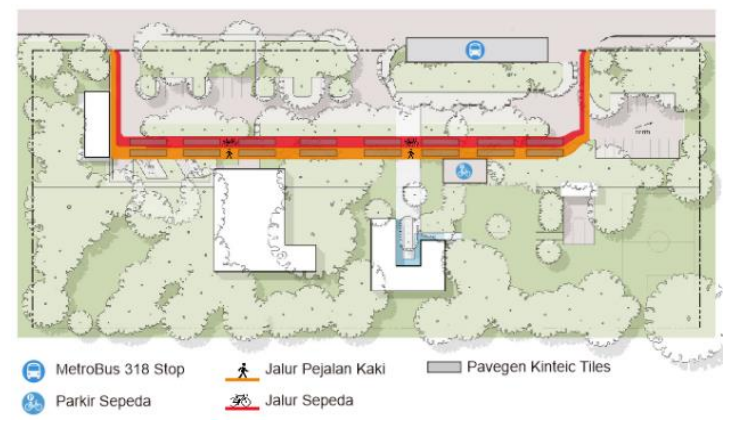

Gambar 9. Desain siteplan

Pada desain awal The Khabele School hanya mendapatkan poin 15. Untuk meningkatkan nilai bangunan dan juga meningkatkan 
sustainable bangunan itu sendiri maka penulis memberikan rekomendasi desain (lihat Gambar 8 dan Gambar 9). Dari hasil uji ulang yang dilakukan desain rekomendasi ini mendapatkan poin 60 , yang mana poin tersebut lebih tinggi 45 poin dari desain awal.

Tabel 8. Hasil evaluasi ulang zero carbon mobility dengan menerapkan rekomendasi desain

\begin{tabular}{|c|c|c|c|c|}
\hline Indikator & Tolak ukur & Ada & $\begin{array}{l}\text { Tidak } \\
\text { Ada }\end{array}$ & Poin \\
\hline Pedestrian & $\begin{array}{l}\text { Infrastruktur jalur } \\
\text { pejalan kaki }\end{array}$ & $\mathrm{v}$ & & 5 \\
\hline \multirow{6}{*}{ Sepeda } & $\begin{array}{l}\text { Parkir mudah } \\
\text { diakses }\end{array}$ & $\mathrm{v}$ & & 5 \\
\hline & $\begin{array}{l}\text { Parkir terlindung } \\
\text { dari cuaca min } 80 \%\end{array}$ & $\mathrm{v}$ & & 5 \\
\hline & $\begin{array}{l}\text { Pencahayaan parkir } \\
\text { memadai min } 80 \%\end{array}$ & $\mathrm{v}$ & & 5 \\
\hline & Parkir aman & $\mathrm{v}$ & & 5 \\
\hline & Bengkel sepeda & & $\mathrm{V}$ & 5 \\
\hline & Pom listrik & & $\mathrm{V}$ & 10 \\
\hline \multirow{2}{*}{$\begin{array}{l}\text { Kendaraan } \\
\text { umum }\end{array}$} & $\begin{array}{l}\text { Jarak pemberhentian } \\
\max 350 \mathrm{~m}\end{array}$ & $\mathrm{v}$ & & 10 \\
\hline & $\begin{array}{l}\text { Infrastruktur } \\
\text { pendukung }\end{array}$ & $\mathrm{v}$ & & 15 \\
\hline $\begin{array}{l}\text { Kendaraan } \\
\text { pribadi }\end{array}$ & $\begin{array}{l}\text { Pom listrik } \\
\text { kendaraan }\end{array}$ & & $\mathrm{v}$ & 5 \\
\hline $\begin{array}{l}\text { Kendaraan } \\
\text { bersama }\end{array}$ & $\begin{array}{l}\text { Kendaraan bersama } \\
\text { tersedia }\end{array}$ & $\mathrm{v}$ & & 10 \\
\hline
\end{tabular}

\section{KESIMPULAN}

Setelah dilakukan evaluasi pada The Khabele School menggunkan sistem sertifikasi DGNB dalam empat indikator yang berbeda yaitu biotope area factor (BAF), indoor air quality (IAQ), daylight factor (DF) dan zero carbon mobility. Dari keempat indikator yang dinilai dengan keadaan existing bangunan, terdapat dua indikator yang sudah dapat memenuhi standar yang diterapkan yaitu indoor air quality (IAQ) dan daylight factor (DF), sedangkan dua indikator lainnya belum dapat memenuhi standar. Pada ke-empat indikator tersebut, penulis memberikan rekomendasi desain dan sistem teknologi yang dapat diterapkan pada bangunan. Hal tersebut dimaksudkan agar bangunan yang menjadi objek evaluasi, dapat secara maksimal dalam mengatasi permasalahan polusi udara, yang dapat disimpulkan seperti berikut.

Pertama, biotope area factor (BAF), strategi yang dilakukan adalah dengan menerapkan green walls dengan mempertimbangkan luas yang terbatas. Sistem teknologi rekomendasi yang dipilih yaitu Naava Smart Green Walls, alasan pemilihan teknologi ini karena memiliki keunggalan seperti flexible solution, one product many functions, dan easy maintenance. Dengan menggunakan rekomendasi desain, hasil evaluasi ulang BAF naik dari 0,46 menjadi 0,61 memenuhi standar yang diminta.

Kedua, daylight factor (DF) dan indoor air quality (IAQ) The Khabele School sudah dapat mencapai target yang menjadi standar yang ada dalam DGNB. Namun masih ada kekurangan yang dapat ditingkatkan, sehingga bangunan dapat menjadi lebih baik lagi. DF dan IAQ memiliki satu solusi yang sama yaitu bukaan, sehingga menggabungkan aspek keduanya dengan satu teknologi skylight dapat menjadi srategi desain yang lebih baik dalam segi investasi. Sistem teknologi yang digunakan yaitu Velux Skylight, dipilih karena selain dapat memasukan cahaya alami, skylight ini dilengkapi dengan sensor suhu, kelembapan dan $\mathrm{CO} 2$, sehingga nilai IAQ dapat terus terkontrol.

Ketiga, Zero carbon mobility, rekomendasi desain yang dilakukan adalah dengan meningkatkan pembangunan infrastruktur dalam aspek pesepeda (jalur sepeda, parker sepeda), aspek kendaraan umum (fasilitas pemberhentian bus), dan aspek teknologi (Pavegen Kinetic Tiles). Teknologi Pavegen diperlukan untuk memberikan nilai lebih ke bangunan yang bermanfaat bagi bangunan dan juga bagi lingkungan, sehingga tidak hanya mendapatkan nilai lebih pada DGNB namun juga memberikan nilai sustainable yang lebih baik.

Kemajuan teknologi yang pesat di semua aspek kehidupan, memberikan peluang bagi bangunan untuk melakukan investasi di dalam teknologi. Investasi tersebut akan membawa bangunan memiliki nilai lebih, tidak hanya di dalam penilaian sertifikasi namun juga meningkatkan bangunan dalam aspek sustainability yang bermanfaat bagi kehidupan generasi mendatang terutama dalam mengartasi isu polusi udara.

\section{UCAPAN TERIMAKASIH}

Penulis mengucapkan terimakasih kepada pihak-pihak yang telah membantu dalam penyusunan paper ini, terutama pihak Program Profesi Arsitektur Universitas Islam Indonesia 
(PPAr UII) yang turut serta memberikan dukungan sehingga terselesaikannya paper ini dengan baik.

\section{REFERENSI}

Basri, \& Setiawan, I. (2012). Jalur Hijau (Green Belt) sebagai Kontrol Polusi Udara Hubungannya dengan Kualitas Hidup di Perkotaan. Keberlanjutan Kota, 7.

DGNB. (2018). Version 2018. Available: https://www.dgnb.de/de/index.php [accessed 12.11.2020]

DGNB. (2020). Buildings in Use. Available: https://static.dgnb.de/ [accessed 12.11.2020]

Hedrick, R. L., Thomann, W. R., Mcfarland, J. K., Alevantis, L. E., Berlin, G. L., Brunner, G., ... Hall, R. L. (2013). Ventilation for acceptable indoor air quality. ASHRAE Standard, 2013(62.1-2013). Retrieved from www.ashrae.org

Jaung, W., Carrasco, L. R., Shaikh, S. F. E. A., Tan, P. Y., \& Richards, D. R. (2020). Temperature and air pollution reductions by urban green spaces are highly valued in a tropical city-state. Urban Forestry and Urban Greening, 55. https://doi.org/10.1016/j.ufug.2020.126827

Kumar, P., Druckman, A., Gallagher, J., Gatersleben, B., Allison, S., Eisenman, T. S., .. Morawska, L. (2019, December 1). The nexus between air pollution, green infrastructure and human health. Environment International, Vol. 133. https://doi.org/10.1016/j.envint.2019.10518 1

Kusminingrum, N. (2018). Efektifitas Reduksi Polusi Udara dengan Metode Vertical Garden (The Effectiveness of Air Pollution Reduction with Vertical Garden Method). In Jurnal Jalan-Jembatan (Vol. 33).

Liu, Z., Hanley, N., \& Campbell, D. (2020). Linking urban air pollution with residents' willingness to pay for greenspace: A choice experiment study in Beijing. Journal of Environmental Economics and Management, 104. https://doi.org/10.1016/j.jeem.2020.102383

Lu, J., Li, B., Li, H., \& Al-Barakani, A. (2021). Expansion of city scale, traffic modes, traffic congestion, and air pollution. Cities, 108.https://doi.org/10.1016/j.cities.2020.10 2974

Morakinyo, T. E., Lam, Y. F., \& Hao, S. (2016). Evaluating the role of green infrastructures on near-road pollutant dispersion and removal: Modelling and measurement. Journal of Environmental Management, 182, 595-605. https://doi.org/10.1016/j.jenvman.2016.07 .077

Naava. (2020). Naava N-series. Available: https://www.naava.io/en/ [accessed 7.12.2020]

Olesen, B. W. (2015). Indoor environmental input parameters for design and assessment of energy performance of buildings. REHVA Journal, 17-23.

Pavegen (2020).

Pavegen. https://pavegen.com/about/ [accessed 7.12.2020]

Ranjbar, A. (2019). Analysing the effects of thermal comfort and indoor air quality in design studios and classrooms on student performance. IOP Conference Series: Materials Science and Engineering, 609(4). https://doi.org/10.1088/1757899X/609/4/042086

Taleghani, M., Clark, A., Swan, W., \& Mohegh, A. (2020). Air pollution in a microclimate; the impact of different green barriers on the dispersion. Science of the Total Environment, 711. https://doi.org/10.1016/j.scitotenv.2019.1 34649

Veluxsa. (2020). The Solar Powered "Fresh Air" Skylight. Available: https://www.veluxusa.com/products/skyli ghts [accessed 7.12.2020]

Yang, J., Shi, B., Shi, Y., Marvin, S., Zheng, Y., \& Xia, G. (2020). Air pollution dispersal in high density urban areas: Research on the triadic relation of wind, air pollution, and urban form. Sustainable Cities and Society, 54. https://doi.org/10.1016/j.scs.2019.101941

Zhang, S., Wang, B., Wang, S., Hu, W., Wen, X., Shao, P., \& Fan, J. (2020). Influence of Air Pollution on Human Comfort in Five Typical Chinese Cities. Environmental Research, 110318. https://doi.org/10.1016/j.envres.2020.110 318 